\title{
Evaluation of a blended learning model for pre-service teachers
}

\author{
Laura Martín-Martínez \\ Vanesa Sainz \\ Fidel Rodríguez-Legendre
}

Universidad Francisco de Vitoria, Madrid, Spain

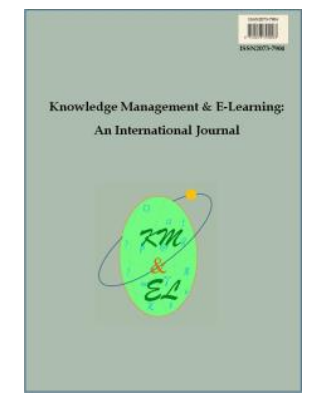

Knowledge Management \& E-Learning: An International Journal (KM\&EL) ISSN 2073-7904

\section{Recommended citation:}

Martín-Martínez, L., Sainz, V., \& Rodríguez-Legendre, F. (2020). Evaluation of a blended learning model for pre-service teachers. Knowledge Management \& E-Learning, 12(2), 147-164. 


\title{
Evaluation of a blended learning model for pre-service teachers
}

\section{Laura Martín-Martínez}

Facultad de Educación y Psicología

Universidad Francisco de Vitoria, Madrid, Spain

E-mail: 1.martin.prof@ufv.es

\section{Vanesa Sainz*}

Facultad de Educación y Psicología

Universidad Francisco de Vitoria, Madrid, Spain

E-mail: vanesa.sainz@ufv.es

\section{Fidel Rodríguez-Legendre}

Facultad de Educación y Psicología

Universidad Francisco de Vitoria, Madrid, Spain

E-mail: f.rodriguez.prof@ufv.es

*Corresponding author

\begin{abstract}
This study aims to determine the predictive factors for effective teaching in blended learning contexts. A Blended Learning Evaluation Scale was devised. The participants were 145 first-year students studying for education degrees using a blended learning model. An exploratory factorial analysis revealed five factors for establishing a good model of blended teaching and learning: student expectations on their learning subjects, the use of web 2.0 tools, feedback from teachers, collaborative work among fellow classmates, and the social relations among students themselves and with their professors.
\end{abstract}

Keywords: Blended learning; e-Learning; Pre-service teacher; Web 2.0; Collaborative learning; Feedback

Biographical notes: Dr. Laura Martín-Martínez is Director of Department of Education and full-time professor in Universidad Francisco de Vitoria, Madrid, Spain. She is doctoral graduate in teaching methodologies and e-learning at Universidad Autónoma de Madrid. Her research interests include attention to diversity, cooperative learning, educational inclusion and technologies in education.

Dr. Vanesa Sainz is a full professor at the Faculty of Education and Psychology in Universidad Francisco de Vitoria, Madrid, Spain. She is a psychologist and completed her $\mathrm{PhD}$ in education at Universidad Autónoma de Madrid with interests in technology. She has taught courses and degrees for students in data analysis, methodology and psychologist.

Dr. Fidel Rodríguez-Legendre is Vice Dean of Research and full professor at the Faculty of Education and Psychology in Universidad Francisco de Vitoria, Madrid, Spain. He completed his PhD in Communication Sciences and 
Sociology at Faculty of Information Sciences in Universidad Complutense de Madrid. He is currently teaching courses of sociology and sciences.

\section{Introduction}

In the current historical-educational context, we are immersed in the digital age which turns on the use of information technologies, enabling us to communicate at a distance and fostering social progress within a globalised and interconnected world. It cannot be denied that the incorporation of digital technologies and the development of the Internet have prompted a change in education methodologies. This impact is even greater in higher education and in university studies (Sohrabi, Vanani, \& Iraj, 2019).

The demands of contemporary society, and of our education system, are very different from what they were in the past. The demand for immediacy has led to the development of study programmes different from the traditional in-person methodologies, such as flipped classroom, to adapt to the changing needs of students. It is important that students are active participants in their own learning, interacting with their peers, collaborating with each other and with flexible access to information and resources (Brahimi \& Sarirete, 2015). This is made possible through the use of information and communication technologies (ICT) in the field of education.

Education should promote methodologies that facilitate learning without personal attendance, and higher education institutions have seen the need to develop remote learning programmes, such as e-learning, and blended learning modalities.Mixed-mode or hybrid learning has its greatest impact in higher education, where students and professors access globalised information as a matter of course, rapidly and dynamically. New technologies provide access to the latest developments in the different fields of knowledge, as shown in the most recent scientific research. Thus, universities have intensified their efforts to accommodate these demands. By aiming to facilitate learning through a methodology which helps students balance the various personal, professional and social aspects of their lives, we further one of the basic principles of education: individualised learning, understood as adaptation to the needs of the person.

The present research was conducted on the basis of these considerations, with the aim of determining the factors which help predict the most effective learning outcomes for blended learning. With this approach, we identify the basic elements professors and institutions must consider when in practicing this learning methodology. In accordance with the above, the following research questions were posed:

1. What are the predictive variables of a good methodological approach in blended learning modality?

2. What tools and resources do professor provide to pre-service teachers through the virtual platform in the blended learning modality?

3. How are the tools and resources provided through the virtual platform used by pre-service teachers in blended learning modality?

\section{Literature review}

e-Learning is a teaching methodology that does not require the presence or meeting of students with the teacher in any physical location (Area \& Adell, 2009; Cabero, 2006). 
Thus, e-learning allows students to learn at any time and in any place (Goda et al., 2015), using new information technologies, computers, mobile phones, tablets and the Internet (Nedungadi \& Raman, 2012). These digital teaching spaces, known as virtual classrooms, entail innovations in the methodological and didactic process, supported by the continuous use of technology (Bartolomé Pina, 2004). By means of these learning strategies, the student has access to the materials and can interact with the teacher.

Blended learning consists of a combination of teaching-learning methodologies developed in real spaces or classrooms, together with other processes using online tools (Bartolomé Pina, 2004; Caravias, 2015; Graham, Allen, \& Ure, 2005; Picciano \& Dziuban, 2007; Ramírez-Martinell \& Maldonado Berea, 2015). The intention with this methodology is to harness the advantages of the in-person modality while incorporating the technological and communicative strategies furnished by distance education through an interactive and vibrant learning environment (Sohrabi et al., 2019).

Studies appraising the differential efficacy of teaching-learning methodologies have found that the blended learning model yields better results in higher education than either the online-only approach (Bicen, Ozdamli, \& Uzunboyly, 2014) or traditional classroom learning (Bernard, Borokhovski, Schmid, Tamim, \& Abrami, 2014). Thus, we have seen a growing trend in the use of blended learning in teacher training programmes (Paniagua, Luengo, Torres-Carvalho, \& Casas, 2017). Attitudes towards and experience with technology are key factors in predicting the intentions of using blended learning (Bervell \& Umar, 2018).

The importance of e-learning and blended learning has also recognised in the Europe-wide process of convergence in creating the European Higher Education Area (EHEA), which proposes substantial changes in pedagogical models and in the role of both professors and students (Barragan et al., 2009). This type of teaching is changing the way we learn, communicate and work, with a much more active role assigned to students in their own learning experience (Miller et al., 2013). The student organises their own academic and motivational objectives, marshalling available resources on the basis of their specific needs and circumstances (Bandura, 1997).

Keengwe and Kang (2013) showed that online learning environments foster the active development of practical skills in students, increasing student participation and improving the learning process and outcomes (Yilmaz \& Keser, 2016). Distance education requires overcoming the paradigms of scheduled time and space, thereby fostering the autonomy, flexibility and independence of the student (Freire-Tigreros, Gómez-Zermeño, \& García-Vázquez, 2016). Arasaratnam-Smith and Northcote (2017) identify four ways in which online learning can benefit students: social egalitarianism, emphasis on verbal/written proficiency, time for reasoned response, and social agency.

The role of the professor in distance learning is also different. The professor becomes a facilitator, providing access to searches for information and stimulating student reflection, dialogue and participation using technological platforms. The study by Imbernón Muñoz, Silva García, and Guzmán Valenzuela (2011), identified the competences required of teachers for successful learning outcomes for students through virtual contexts. Teachers must have computer and telematic skills, be able to plan and design techniques for the virtual environment and be able to deploy suitable didactic methodologies in these modalities.

This type of teaching has assumed a fundamental role in the university education through the introduction of information and communication technologies (ICT) as key tools in invigorating student learning (Imbernón Muñoz et al., 2011). However, recent 
research (Olaniran, Duma, \& Nzima, 2017) shows that while the electronic resources are available and accessed, the majority of the pre-service teacher trainees have not been utilizing the e-learning resources in the classroom. Other findings revealed that teachers use technology for teaching and learning progressively and within their comfort zone (Sadeck \& Cronjé, 2017).

Reviewing available literature, González Aldana, Perdomo Osorio, and Pascuas Rengifo, (2017) recognised the importance of using ICT and of the interaction between teacher and student when using this methodology. They highlighted the positive impact educational development on different technologies, such as educational platforms (Muñoz Carril \& González Sanmamed, 2009), virtual forums and social media, including blogs, Facebook, Twitter and Youtube, which help enrich and facilitate the learning experience (Li, 2018). Distance learning in higher education is supported by web 2.0 ICT tools and e-learning resources (Bartolomé Pina, 2012; Wang, Love, Klinc, Kim, \& Davis, 2012; Yang, 2013).

Deploying the technology this methodology requires poses the challenge of making responsible and mature use of the benefits offered by the digital world. In these educational settings, strongly mediated by digital artefacts, it is important to establish standards in good practices (Carmona \& Rodríguez, 2017). It is also necessary to develop procedures which facilitate the distribution and sharing of knowledge through interaction and dialogue in producing and implementing technological resources. It has been shown that proper use of such tools permits rapid and effective interaction, reciprocity and collaboration between the professor and student.

Communication and motivation in students are fundamental factors in developing teaching plans (Yilmaz, 2017). Therefore, in online or blended learning processes, communication and social interaction between teacher and students is essential (Prieto, 2016). Blended learning requires adequate support and the fostering of social interactions among students and with the teacher (Bernard et al., 2014). Blended learning allows the student to engage in cooperative and participatory activities (Levy, 2008). The cooperative model fosters teamwork, debate and problem-solving both in-person and using online tools (Anderson \& Dron, 2011). As Dias and Diniz (2014) note, blended education should integrate collaborative and interactive learning activities.

Other authors (Borup, Wes, \& Thomas, 2015) highlight the importance of feedback received by students in this type of teaching. The researchers found no significant differences between video and text feedback while pointing out different advantages depending on the type of feedback given: text enables more efficient and organized feedback, while video encourages supportive and conversational communication. The use of digital resources in education has prompted research into the forms in which these strategies are adapted and applied to the teaching-learning process in the university context.

In relation to university teaching strategies, the Horizon Report 2017 Higher Education Edition (Adams Becker et al., 2017) is of particular interest. Among the challenges and developments in technologies aimed at teaching, immediate trends point to online learning, the use of mobile devices and blended learning. According to the report, the perception of this kind of teaching has changed for the better, as both students and teachers regard it as a viable alternative to in-person classes, and blended learning is increasingly prevalent at all levels of education. As a consequence, there is an increasing number of digital learning platforms which are applied in various ways. The report concludes that this kind of teaching enhances creative thinking, independent study, and the adaptation of learning experience by students to match their concerns and needs. 
A study by Hinojo, Aznar, and Cáceres (2009) examines university student perceptions of blended learning, concluding that blended learning combines the most positive aspects of in-person learning (direct work) with the most beneficial aspects of distance learning (interaction, rapidity and economy). According to the study, the features differentiating the blended learning model are improved skills development, the use of group practices and dynamics and better problem solving through teamwork, compared with study through an exclusively e-learning methodology.

Other studies (Robles Haros, Fernández Nistal, \& Vales García, 2016) have looked at the perceptions of teachers in the blended learning modality, reaching the conclusion that its greatest advantages lie in the transfer of information, the application of concepts, the exchange of ideas, the distribution of resources and the creation of collaborative knowledge.

Surveys of university student perceptions reveal that the most important competencies gained in a blended learning environment are problem-solving, computer skills and the overall usefulness of electronic learning (Keržič, Aristovnik, Tomaževič, \& Umek, 2018). The study by Goh, Leong, Kasmin, Hii, and Tan (2017) identified course design, interaction with the instructor and interaction with fellow students are highly predictive factors of learning outcomes and satisfaction with the electronic learning.

Research by Gámiz Sánchez and Gallego Arrufat (2016) establishes a multidimensional model for analysing blended learning methodologies in higher education. In this study, the authors assessed the actions and opinions of students and professors, as well as the statistics on access and use of the platform. The results show that students using this methodology feel that it fosters independent learning and selfregulation. The authors also observe that use of the platform facilitates student participation in practical exercises, while boosting student motivation, autonomy and responsibility in pursuing their own learning. Further, this methodology is highly flexible in terms of time and space, permitting access to resources anytime and anywhere.

In terms of flexibility, interactivity, cooperation and self-management, a quantitative study was conducted (Freire-Tigreros et al., 2016) to evaluate blended learning practice in higher education, using a student questionnaire. A study by Castaño, Jenaro, and Flores (2017) also analysed the impressions of students studying for a degree in primary education, with regard to training using blended learning.

Reviewing previous research, it can be observed that the blended learning modality requires technological and digital media (Bervell \& Umar, 2018; González Aldana et al., 2017), web 2.0 tools (Bartolomé Pina, 2012; Wang et al., 2012; Yang, 2013), interaction and collaboration between classmates and professors (Bernard et al., 2014; Goh et al., 2017; Prieto, 2016), collaborative and interactive learning activities (Anderson \& Dron, 2011; Dias \& Diniz, 2014; Levy, 2008), an active student role in their learning (Keengwe \& Kang, 2013; Miller et al., 2013), student motivation (Yilmaz, 2017) and feedback from professors to the students about their learning (Borup et al., 2015).

Given the importance blended learning has acquired, it is essential to identify clearly the most substantive elements that enable the effective implementation of this modality for university teaching. There is no doubt that higher education has been transformed by blended learning in recent years, requiring continuous teacher training in the application of resources and strategies to help students learn with the same effectiveness as in face-to-face or traditional teaching. Therefore, given the importance of blended learning in current university studies, this research sets out the following goals: 
- To discover the predictive variables of a good methodological approach in blended learning.

- To identify the resources and key elements that professors must take into account in using the blended learning modality.

- To put forward proposals for the optimization and improvement of teacher training in blended learning.

It is important to identify the most effective elements of quality blended learning, avoiding the sense of loneliness that students may feel in this teaching-learning modality.

\section{Method}

\subsection{Participants}

The participants in this study were 145 first-year students of the pre-primary and primary education degree courses at La Salle University in Madrid (Spain). This University was chosen as it was the first to have applied the online modality for teacher training in Spain.

The participants were selected using purposive sampling, taking all first-year students of the pre-primary $(68 \%)$ and primary $(32 \%)$ education degree courses using blended learning at that moment. In this modality, students have access to the course contents and can communicate with their professor using the University platform; students are required to attend one classroom session per month for each subject they are taking. It was decided to select first-year students as they would have no prior knowledge of the use of the tools of the University platform. The platform used by La Salle University is the commercial tool LMS LUVIT (Muñoz Carril \& González Sanmamed, 2009), created at Lund University in Sweden.

In their assessment of the platform, $79 \%$ of sampled students believe the virtual platform is easy to use, with $65 \%$ of them having received initial training to use it. $54 \%$ of participants claim to have received technical assistance when they encountered difficulties in using the platform. Participants use the platform to check the date of their exams $(98 \%)$, check class schedules $(92 \%)$, check their marks (82\%), deliver assignments $(57 \%)$, consult library books $(6 \%)$, communicate with their classmates $(86 \%)$ and to communicate with professors (45\%). However, $59 \%$ of students prefer to use email when communicating with professors. Professors use the virtual platform to post the course notes $(97.1 \%)$, schemes $(62 \%)$, interesting websites $(78 \%)$, interactive talks $(7.5 \%)$, forums $(23,4 \%)$, blogs $(1.9 \%)$, videos $(9.9 \%)$, self-assessments with automatic correction $(25.5 \%)$, self-assessments without automatic correction $(47.9 \%)$, model exams $(39.2 \%)$ and glossaries $(33.9 \%)$.

The courses taken by participants in the first year of their degree using blended learning were: general didactics, psycho-pedagogical foundations of special education, educational research and developmental psychology. Of the registered students, $69 \%$ say they chose the degree because of vocation. Nevertheless, $40 \%$ of the participants entered the programme after taking a different university degree (psychology, philosophy, engineering, business, marketing, tourism, among others) and $37 \%$ of participants entered after obtaining higher technical certificate.

$72 \%$ of the participants reside in the Community of Madrid (where La Salle University is located), $18 \%$ are from other Autonomous Communities (Aragon, Castilla y 
Leon, Cataluña, Navarra, Castilla la Mancha, Cantabria, País Vasco, Galicia and Islas Baleares) while the remaining $10 \%$ did not state their place of residence.

Regarding the age of participants, Fig. 1 shows that the bulk of students are aged from 21 to 35 years, $72 \%$ of the sample.

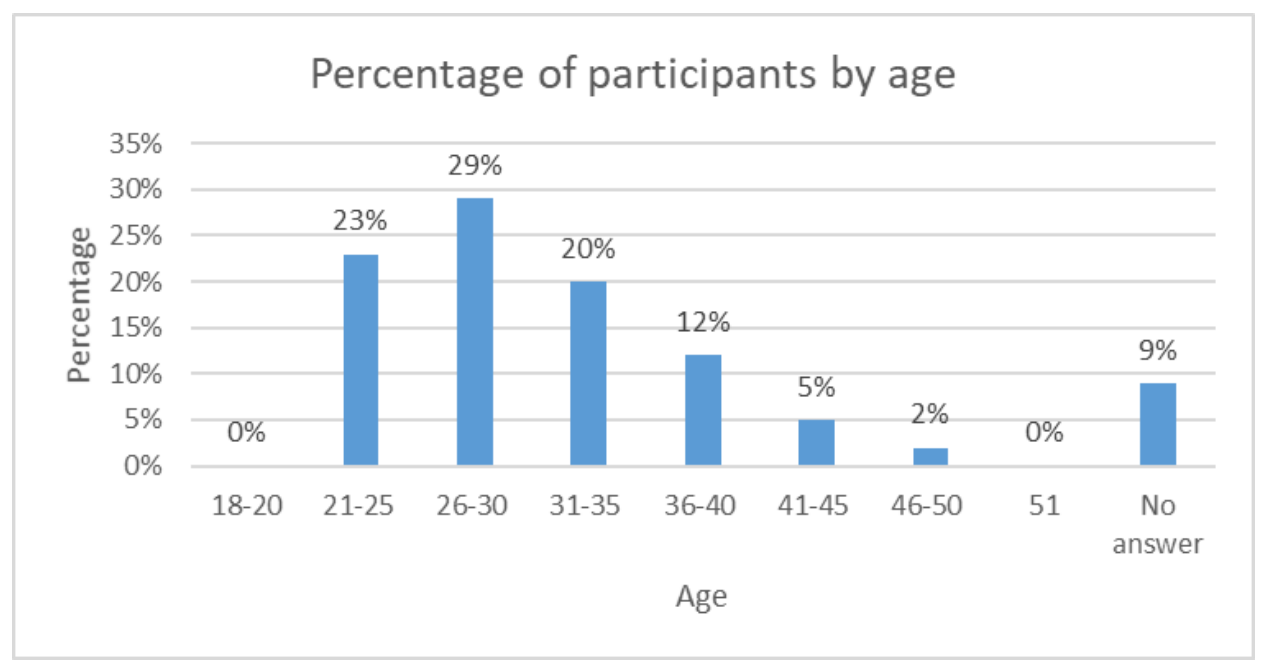

Fig. 1. Age distribution of participants

It is important to note that $89 \%$ of the students using this kind of teaching modality are working while studying. Furthermore, $68 \%$ of working students are in fulltime employment, more than 30 hours per week. Additionally, 54\% of working learners are employed in the field of education. Regarding the availability of a computer, $100 \%$ of the participants have a computer at home and $93 \%$ have an internet connection.

\subsection{Instrument}

An evaluation scale was defined to identify the tools which facilitate blended learning:

Blended Learning Evaluation Scale (BLES) (Appendix I), structured into two blocks.

The first block of the questionnaire consists of 10 questions about the sociodemographic background of the participants. The purpose was to obtain a general profile of the students registered in the blended learning modality.

The second block evaluates more specific aspects of the methodology as used in different subjects (Teaching, Educational Research, Developmental Psychology and Psycho-pedagogical Foundations), and the variables which predict good teaching practices. This block consists of 23 Yes/No questions and 15 multiple-choice questions using the Likert scale, with 6 possible responses ranked as follows: 1-Not at all, 2-A little, 3-Somewhat, 4-Fairly, 5-A lot, 6-Very much. The Yes/No questions allowed a frequency analysis to be performed and were used as filters to discriminate among the participants in the multiple-choice questions. The Likert scale questions describe items relating to the predictive variables for the effectiveness of the outcome of blended learning and were used to perform an exploratory factorial analysis of the instrument. 


\subsection{Procedure and analysis}

As part of the research, the instrument was first designed and then subsequently validated and reviewed by experts in distance and blended learning. The participants later answered the questionnaire, sent to them online. The confidentiality of student identities was respected at all times, with the identifying data such as names and ID numbers being retained. Finally, the data was analysed using a factorial analysis model.

The methodological approach in this study was ex post facto (retroactive) and quantitative. Based upon this approach, an exploratory factorial analysis was conducted to identify the predictive variables which determine sound planning of blended learning at the university level. The statistical analyses were carried out using the application SPSS, version IBM Statistics 22, to process the data from the questionnaires.

\section{Results}

First, to determine the viability of the factorial analysis, the Kaiser-Meyer-Olkin index was calculated, and the Bartlett sphericity test was carried out $(\mathrm{KMO}=.789$; Bartlett: $p<$ $.001)$. These results indicated that the sample and the data matrix were well-suited to factorial analysis. Furthermore, the results of the correlation matrix show values of 1 on the diagonal and close to 0 elsewhere. These figures show that the correlation is low, favouring the other analyses presented. From the analyses we can conclude that the factorial analysis of the principal components is viable and appropriate for the present study.

When analysing the principal components, five significant factors were extracted whose eigenvalues were greater than 1 . The calculated eigenvalue for factor 1 (Expectations) was 4.62; for factor 2 (Web 2.0 tools), 2.59; for factor 3 (Feedback), 1.45; for factor 4 (Collaborative/cooperative work), 1.24; and for factor 5 (Social relations), 1.09. These factors are significant, allowing $68.65 \%$ of the total variance of the scale to be explained. The distribution of this variance is $28.87 \%, 16.17 \%, 9.08 \%, 7.72 \%$ and $6.81 \%$ respectively, for each of the factors. Table 1 shows the eigenvalues and the percentage variance explained by each factor in the Blended Learning Evaluation Scale.

Table 1

Eigenvalues and variances for each factor

\begin{tabular}{lccc}
\hline Factor & Eigenvalue & Variance (\%) & $\begin{array}{c}\text { Cumulative } \\
\text { variance (\%) }\end{array}$ \\
\hline 1. Expectations & 4.62 & 28.87 & 28.87 \\
2. Web 2.0 tools & 2.59 & 16.17 & 45.04 \\
3. Feedback & 1.45 & 9.08 & 54.12 \\
4. Collaborative work & 1.24 & 7.72 & 61.84 \\
5. Social relations & 1.09 & 6.81 & 68.65 \\
\hline
\end{tabular}

An exploratory factorial analysis was subsequently performed using principal components with varimax rotation, with the aim of identifying the variables which correlate with each of the five factors obtained. In Table 2, the matrix of rotated components for each of the variables analysed in the "Blended Learning Evaluation 
Scale" is presented. Highlighted in bold, we can see the factorial loadings of the variables associated to the factor grouping them together.

Table 2

Matrix of rotated components for the BLES

\begin{tabular}{|c|c|c|c|c|c|}
\hline \multirow{2}{*}{ Items } & \multicolumn{5}{|c|}{ Factors } \\
\hline & 1 & 2 & 3 & 4 & 5 \\
\hline Item 1. Usefulness of email for asking the professor questions & .25 & .10 & .59 & .05 & .37 \\
\hline Item 2. Usefulness of work in groups & .11 & .32 & .00 & .78 & .08 \\
\hline Item 3. Usefulness of presenting group work in class & .08 & .35 & .18 & .70 & -.06 \\
\hline Item 4. Usefulness of return of corrected work & .17 & .12 & .78 & .03 & -.06 \\
\hline Item 5. Usefulness of handing in work to the professor using the platform & .01 & .06 & .73 & .08 & .05 \\
\hline Item 6 . Usefulness of chats & -.01 & .87 & .05 & .12 & .08 \\
\hline Item 7. Usefulness of forums & .04 & .81 & .11 & .34 & .06 \\
\hline Item 8. Usefulness of blogs & .00 & .87 & .08 & .07 & .11 \\
\hline Item 9. Closeness of relationship with the professor & .17 & .13 & .05 & .06 & .85 \\
\hline Item 10. Closeness of relationship with classmates & .04 & .09 & -.07 & .54 & .63 \\
\hline Item 11. Communication with the professor (by email or in class...) & .25 & .08 & .40 & -.15 & .60 \\
\hline Item 12. Usefulness of the subject for practical teaching & .88 & .11 & .23 & -.06 & .12 \\
\hline Item 13. Applicability of the contents in the classroom & .90 & .08 & .19 & -.01 & .11 \\
\hline Item 14. Initial motivation for the subject & .59 & -.17 & -.02 & .35 & -.01 \\
\hline Item 15. Final motivation for the subject & .80 & .01 & .08 & .20 & .26 \\
\hline
\end{tabular}

Note. Extraction method: principal components analysis. Rotation method: varimax normalisation with Kaiser. The rotation converged in 6 interactions.

After the exploratory factorial analysis, five factors were obtained for the Blended Learning Evaluation Scale. We then proceeded to analyse each of these factors by relocating the variables or associated items to each of them and their communality.

The first factor groups together four variables related to what the student expects to learn and their motivation for the subjects. The variables include usefulness of the subject for practical teaching (with a communality of 0.851 ), applicability of the contents in the classroom (communality 0.868), initial motivation for the subject (communality 0.500 ), and final motivation for the subject (communality of 0.753 ). In view of the items included in this component, it was decided to designate this factor as "Expectations".

The second factor brings together three variables related to the usefulness of the communicative tools and interaction over the Internet. The items include the usefulness of chats (with a communality of 0.778 ), the usefulness of forums (communality of 0.787 ), and the usefulness of blogs (communality of 0.773). This factor was called "Web 2.0 tools".

The third factor groups three variables associated to the feedback received by students. The items include the usefulness of email for asking the professor questions (with a communality of 0.556 ), the usefulness of receiving corrected work (communality of 0.654 ), and the usefulness of handing in work using the platform (communality of 0.548). This factor was given the name "Feedback". 
The fourth factor combines two variables related to the influence and benefits of teamwork: The items associated to this factor are: the usefulness of work in groups (with a communality of 0.735 ), and the usefulness of presenting group work in class (with a communality of 0.651 ). This component was designated "Collaborative/cooperative work".

Finally, the fifth factor brings together three variables relating to closeness and social relations with the professor and classmates. This factors include closeness of relationship with the professor (with a communality of 0.781 ), closeness of relationship with classmates (communality of 0.704) and communication with the professor (communality of 0.609 ). This factor was designated "Social relations".

The figures show that the variable with the highest communality is the applicability of the contents in the classroom, explaining $86.8 \%$ of the variance, while the lowest communality is that for the initial motivation for the subject, accounting for $50 \%$ of the variance. It must be emphasised that all the communalities of the variables meet the criterion demanded, as their values are at least 0.50 .

Fig. 2 shows the five factors of the Blended Learning Evaluation Scale (BLES) and the items associated to each factor.

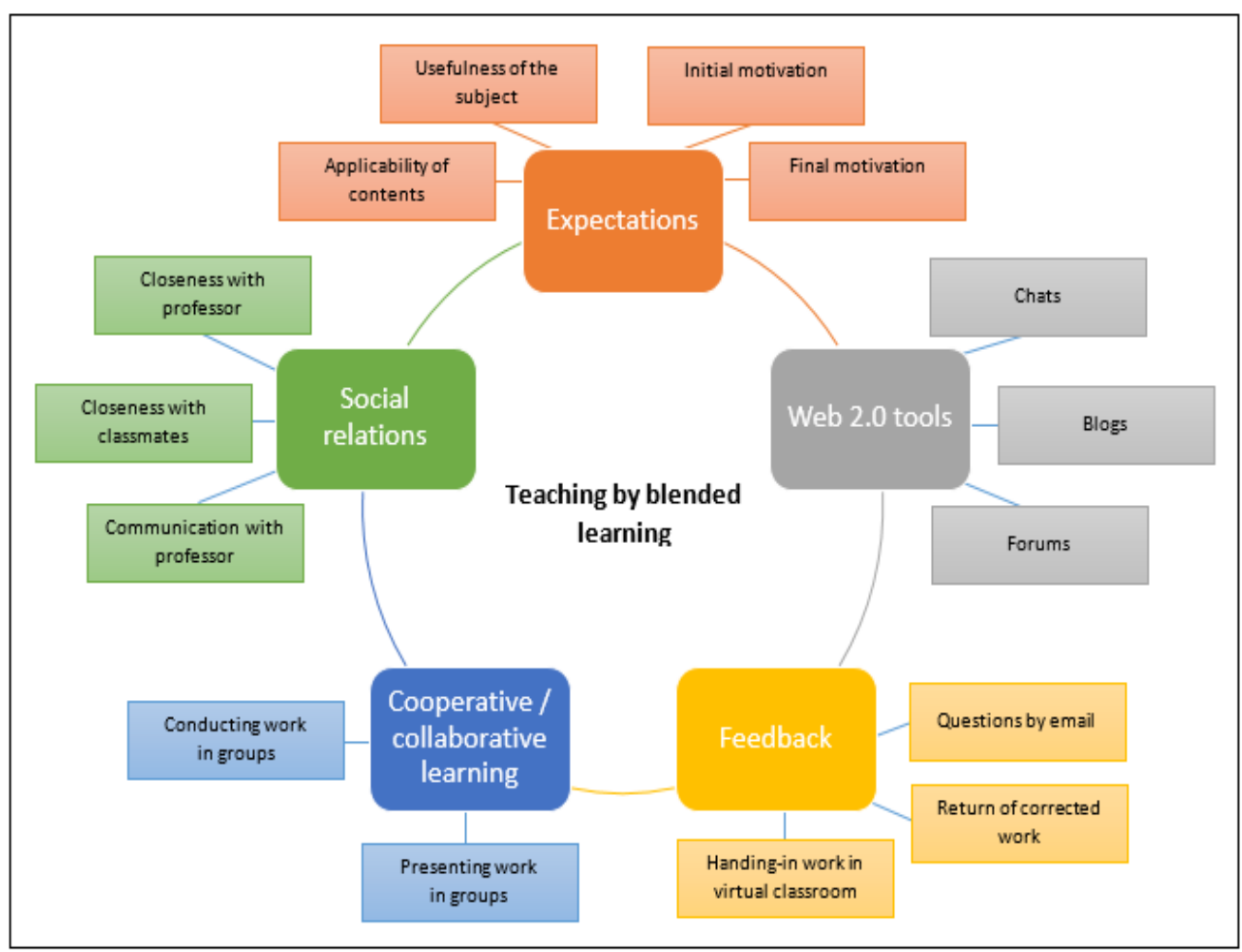

Fig. 2. Factor diagram for the BLES

Thus, with the matrix of rotated factors, the results show that the items of the Blended Learning Evaluation Scale (BLES) are grouped into five factors, defined as Expectations, Web 2.0 tools, Feedback, Collaborative/cooperative work and Social relations. 


\section{Discussion}

The present research has allowed us to identify the most important variables in achieving a good methodological approach in the blended learning modality. The Blended Learning Evaluation Scale (BLES) shows a high degree of consistency in the five dimensions associated with blended learning, obtained from the factorial structure in the data analysis

The variables or categories used in the BLES permit the verification of student expectations and motivation; social relations among classmates and the teacher, the use of electronic devices and other communication tools, feedback from teachers, cooperation and collaboration among classmates are all key factors in ensuring the success of the blended learning model. Thus, in view of the results, the elements essential to an effective blended learning methodology are: "Expectations", "Web 2.0 tools", "Feedback", "Collaborative/cooperative work" and "Social relations".

The factor "Expectations" refers to student motivation and their views on the usefulness of the programme courses and content for their future teaching career. Motivation to learn is a fundamental element in the effectiveness of blended learning, as other authors have shown (Gámiz Sánchez \& Gallego Arrufat, 2016).

The factor "Web 2.0 tools" covers the use of ICT resources (forums, blogs, chats, etc) as optimal facilitators of learning in this modality. In this teaching model, classroom attendance is limited and so communication tools are necessary. The importance of using web 2.0 tools has been highlighted in previous studies (González Aldana et al., 2017; Bartolomé Pina, 2012; Li, 2018; Wang et al., 2012; Yang, 2013).

"Collaborative/cooperative learning" is an important element in achieving effective results in blended learning. As previous studies have shown (González Aldana et al., 2017; Bernard et al., 2014; Prieto, 2016), a collaborative methodology fosters effective learning and the acquisition of the skills necessary for future teaching (assertiveness, conflict resolution, empathy, etc). A sound methodological approach should encompass a variety of strategies which help the student not only to acquire knowledge but also develop the social skills necessary for working with others.

The factor "Social relations" refers to social interaction among students and with professors, not only in the classroom but outside it as well, that is, the closeness of relations between students and with the professor, and the possibilities for interaction and communication. As earlier studies have found (González Aldana et al., 2017; Bernard et al., 2014; Goh et al., 2017; Prieto, 2016), this element takes on even greater importance in distance or blended study. In these teaching modalities, the teacher holds more responsibility for fomenting these relations in a context where classmates do not know each other well.

"Feedback" is what received by students from the teacher and vice versa. This factor has been identified by other authors (Borup et al., 2015; Goh et al., 2017) as a fundamental element in the blended learning modality.

The identification of the most significant factors in blended learning facilitates the effective implementation of this methodology, increasingly prevalent in universities. Thus, all five factors (expectations, web 2.0 tools, feedback, collaborative learning and social relations) must be taken into account by professors when developing their methodology in the blended learning modality.

The findings of this study are in line with those of previous work (Hinojo, Aznar \& Cáceres, 2009; Gámiz Sánchez \& Gallego Arrufat, 2016; Freire-Tigreros et al., 2016; 
Castaño et al., 2017), highlighting the growing implementation of blended learning in university education in order to adapt to the different learning needs of students.

\section{Conclusion}

Blended learning is highly appropriate for use in university contexts, where students often need to juggle and balance their studies with their personal circumstances, family and work responsibilities. This combined methodology offers the most significant benefits of distance education (time flexibility, immediate access to information, rapid and effective communication and continuous updating of contents), together with some of the advantages of in-person teaching, such as physical contact with the teacher and classmates. The application of blended learning methodologies represents a complementary element to teaching which promotes both individual and collaborative knowledge and skills development.

As noted in the results, pre-service teachers who choose to study with a blended learning modality are usually older than students who enrol for the first time in university studies. Furthermore, $89 \%$ of participants combine their studies with work. These results show that both age and work are variables that influence the choice of blended learning.

The study shows that $97.1 \%$ of the professors use the virtual platform to post course notes in blended learning modality for pre-service teachers. Further, $45 \%$ of participants use the platform to be in touch with their teachers and they value it as very important for their learning. Feedback can be given by email, as most times, but it can also be through chat or interactive talks, directly and simultaneously.

However, professors do not take advantage of all the resources offered by the virtual platform and do not use web 2.0 tools fully. Interactive talks are only used by $7.5 \%$ of the participants, perhaps due to the difficulties in simultaneous connection although these tools allow real-time connection and communication from anywhere. Many benefits can be obtained with interactive talks such as resolution of doubts or the explanation of relevant aspects of a course. In addition, this resource allows contact with experts from anywhere in the world to talk and discuss various topics. These videoconferences can be recorded in order to be available at any time.

The forum is another web 2.0 tool rarely used by professors, only $23.4 \%$. However, the forum can be very useful for encouraging communication among students, expressing ideas, reaching a conclusion about a topic, doing group work, sharing information and reflections, conducting research, creating a synthesis, etc. In blended learning, forums are very important for these activities given the limited number of face to face classes in which discuss, analyse, reflect, etc.

The blog is another rarely used web 2.0 tool (only by $1.9 \%$ of professors) despite having many educational advantages. Blogs allow contents to be annotated chronologically. Users can write their contributions and add videos, photos or audio content. Pedagogically it is important that the rest of students can have access to their classmates' work, allowing the pooling of ideas and reflections, expanding knowledge and interaction.

Web 2.0 tools are very useful and should be used more in the blended learning modality. These tools can replace face-to-face teaching providing the platform resources are used in an effective way. Thus, it is necessary to provide professors with technical, pedagogical and methodological training on web 2.0 tools. Training will help teachers to maximise the advantages and the most appropriate times to use them. Furthermore, 
student use of these tools should be mandatory, and they should be guided, mediated and evaluated by the teacher.

\section{Limitations and recommendations}

Despite the limitations posed by the sample selection, size and composition, the present study has applied an effective methodology to identify relevant factors about the blended learning modality. It is important for research to continue into these learning modalities in order to adapt to changing circumstances and realities in our society. In future investigations, it would be useful to replicate this study with other student groups and in other educational contexts, to see how transferable the results are. Replication of this research in future will help to improve planning for the blended learning modality.

As a future proposal, one task left pending for later research is to determine the extent to which the blended learning modality leads to differences in satisfaction, motivation and performance, compared to traditional classroom and e-learning modalities. Such studies will permit corroboration of whether, as suggested by earlier work (Bernard et al., 2014; Bicen et al., 2014), the mixed-mode approach is more effective than other teaching modalities in higher education.

In addition, future studies should analyse whether the factors for successful blended learning outcomes identified in this study (Expectations, Web 2.0 tools, Feedback, Cooperative/Collaborative work and Social relations) depend on the professor or type of courses taught in teacher training programmes.

It would also be useful to analyse the variables which have the greatest impact on the efficacy and degree of student satisfaction using this teaching modality. To this end, it would be of interest for future empirical studies to include other variables such as gender, student personality or course topic, as well as the competences and training of professors. Further, it would be beneficial to carry out research at other educational levels to identify possible differences from university teaching.

Given the continuous advances in information and communication technologies, and their increasing implementation in the teaching process, we need to continue engaging with this line of research. Within the process of transformation in the field of education, the study and research into new models of higher education for the $21 \mathrm{st}$ century is necessary.

The blended learning model requires the adaptation of new methodologies, resources, and tools for optimum learning outcomes while overcoming the constraints of time and distance to meet the learning needs of each student.

\section{ORCID}

Laura Martín-Martínez (iD https://orcid.org/0000-0002-3777-1058

Vanesa Sainz (ID https://orcid.org/0000-0002-8897-3389

Fidel Rodríguez-Legendre (iD https://orcid.org/0000-0002-8329-3712 


\section{References}

Adams Becker, S., Cummins, M., Davis, A., Freeman, A., Hall Giesinger, C., \& Ananthanarayanan, V. (2017). NMC horizon report: 2017 higher education edition. Austin, Texas: The New Media Consortium.

Anderson, T., \& Dron, J. (2011). Three generations of distance education pedagogy. International Review of Research in Open and Distance Learning, 12(3), 80-97.

Arasaratnam-Smith, L. A., \& Northcote, M. (2017). Community in online higher education: Challenges and opportunities. Electronic Journal of e-Learning, 15(2), $188-198$.

Area, M., \& Adell, J. (2009). e-Learning: Enseñar y aprender en espacios virtuales [eLearning: Teaching and learning in virtual spaces] In J. De Pablos (Ed.), Tecnología Educativa. La formación del profesorado en la era de Internet [Training teachers in the internet age] (pp. 391-424). Málaga, España: Aljibe.

Bandura, A. (1977). Self-efficacy: Toward a unifying theory of behavioral change. Psychological Review, 84(2), 191-215.

Barragan, R., García, R., Buzón, O., Rebollo, M. A., \& Vega, L. (2009). E-Portafolios en procesos blended-learning: Innovaciones de la evaluación en los créditos Europeos [E-portfolio in blended-learning processes: Assessment innovations in the European credits transfer system]. Revista de Docencia Universitaria, 7(1): 8.

Bartolomé Pina, A. (2004). Blended learning. Conceptos básicos [Blended learning. Basic concepts.]. Pixel-Bit. Revista de Medios y Educación, 23, 7-20.

Bartolomé Pina, A. (2012). De la web 2.0 al elearning 2.0 [From web 2.0 to e-learning 2.0]. Perspectiva, 30(1), 131-153. doi: 10.5007/2175-795X.2012v30n1p131

Bernard, R. M., Borokhovski, E., Schmid, R. F., Tamim, R. M., \& Abrami, P. C. (2014). A meta-analysis of blended learning and technology use in higher education: From the general to the applied. Journal of Computing in Higher Education, 26(1), 87-122.

Bervell, B., \& Umar, I. N. (2018). Utilization decision towards LMS for blended learning in distance education: Modeling the effects of personality factors in exclusivity. Knowledge Management \& E-Learning, 10(3), 309-333.

Bicen, H., Ozdamli, F., \& Uzunboylu, H. (2014). Online and blended learning approach on instructional multimedia development courses in teacher education. Interactive Learning Environments, 22(4), 529-548.

Borup, J., West, R. E., \& Thomas, R. (2015). The impact of text versus video communication on instructor feedback in blended courses. Educational Technology Research and Development, 63(2), 161-184. doi: 10.1007/s11423-015-9367-8

Brahimi, T., \& Sarirete, A. (2015). Learning outside the classroom through MOOCs. Computers in Human Behavior, 51(Part B), 604-609

Cabero, J. (2006). Bases pedagógicas del e-learning [Pedagogical basis for e-learning]. RUSC. Universities and Knowledge Society Journal, 3(1). doi: 10.7238/rusc.v3i1.265

Caravias, V. (2015). Literature review in conceptions and approaches to teaching using blended learning. International Journal of Innovation in the Digital Economy, 6(3), 46-73.

Carmona, E. J., \& Rodríguez, E. (2017). Buenas prácticas en la educación superior virtual a partir de especificaciones de estándares e-learning [Good practices in virtual higher education through specification of e-learning standards]. Sophia, 13(1), 13-26. doi: 10.18634/sophiaj.13v.1i.345

Castaño, R., Jenaro, C., \& Flores, N. (2017). Percepciones de estudiantes del Grado de Maestro sobre el proceso y resultados de la enseñanza semipresencial-blended learning [Perceptions of education degree students of the process and results of blended learning]. Revista de Educación a Distancia, 52: 2.

Dias, S. B., \& Diniz, J. A. (2014). Towards an enhanced learning management system for 
blended learning in higher education incorporating distinct learners' profiles. Educational Technology \& Society, 17(1), 307-319.

Freire-Tigreros, M. E., Gómez-Zermeño, M. G., \& García-Vázquez, N. Y. (2016). Criterios para el diagnóstico de la práctica educativa a distancia en modalidad BLearning [Criteria for diagnosing distance education practice in the b-learning modality]. Revista Iberoamericana de Tecnología en Educación y Educación en Tecnología, 17, 67-74.

Gámiz Sánchez, V., \& Gallego Arrufat, M. J. (2016). Modelo de análisis de metodologías didácticas semipresenciales en Educación Superior [Model for analysing blended learning in higher education]. Educación XXI, 19(1), 39-61. doi: 10.5944/educXX1.13946

Goda, Y., Yamada, M., Kato, H., Matsuda, T., Saito, Y., \& Miyagawa, H. (2015). Procrastination and other learning behavioral types in e-learning and their relationship with learning outcomes. Learning and Individual Differences, 37, 72-80.

Goh, C., Leong, C., Kasmin, K., Hii, P., \& Tan, O. (2017). Students' experiences, learning outcomes and satisfaction in e-learning. Journal of E-learning and Knowledge Society, 13(2), 117-128.

González Aldana, M. A., Perdomo Osorio, K. V., \& Pascuas Rengifo, Y. (2017). Aplicación de las TIC en modelos educativos blended learning: Una revisión sistemática de literatura [Application of ICT in blended learning models: A systematic literature review]. Sophia, 13(1), 144-154. doi: 10.18634/sophiaj.13v.1i.364

Graham, C. R., Allen, S., \& Ure, D. (2005). Benefits and challenges of blended learning environments. In M. Khosrow-Pour (Ed.), Encyclopedia of Information Science and Technology (pp. 253-259). Hershey, PA: Idea Group Inc.

Hinojo, F. J., Aznar, I., \& Cáceres, M. P. (2009). Percepciones del alumnado sobre el blended learning en la universidad [Student perceptions of blended learning at university]. Comunicar, 33, 165-174. doi:10.3916/c33-2009-03-008

Imbernón Muñoz, F., Silva García, P., \& Guzmán Valenzuela, C. (2011). Teaching skills in virtual and blended learning environments. Comunicar, 36, 107-114. doi: 10.3916/C36-2011-03-01

Keengwe, J., \& kang, J. J. (2013). A review of empirical research on blended learning in teacher education programs. Education and Information Technologies, 18(3), 479493.

Keržič, D., Aristovnik, A., Tomaževič, N., \& Umek, L. (2018). Evaluating the impact of e-learning on studentsperception of acquired competencies in a university blended learning environment. Journal of e-Learning and Knowledge Society, 14(3), 65-76.

Levy, Y. (2008). An empirical development of critical value factors (CVF) of online learning activities: An application of activity theory and cognitive value theory. Computers \& Education, 51(4), 1664-1675. doi: 10.1016/j.compedu.2008.04.003

Li, K. C. (2018). The evolution of open learning: A review of the transition from pre-elearning to the era of e-learning. Knowledge Management \& E-Learning, 10(4), 408425.

Miller, G., Benke, M., Chaloux, B., Ragan, L., Schroeder, R., Smutz, W., \& Swan, K. (2013). Leading the e-learning transformation of higher education: Meeting the challenges of technology and distance education. Sterling, VA: Stylus Publishing.

Muñoz Carril, P. C., \& González Sanmamed, M. (2009). Plataformas de teleformación y herramientas telemáticas [Teletraining platforms and telematic tools]. Barcelona, Spain: UOC.

Nedungadi, P., \& Raman, R. (2012). A new approach to personalization: Integrating elearning and m-learning. Educational Technology Research and Development, 60(4), 659-678. 
Olaniran, S. O., Duma, M. A. N., \& Nzima, D. R. (2017). Assessing the utilization level of e-learning resources among ODL based pre-service teacher trainees. Electronic Journal of e-Learning, 15(5), 384-394.

Paniagua, A., Luengo, R., Torres-Carvalho, J. L., \& Casas, L. M. (2017). Blended learning in the ongoing training of teachers. Contributions of the permanent training advisers on training modalities. RED-Revista de Educación a Distancia, 52: 3.

Picciano, A. G., \& Dziuban, C. D. (2007). Blended learning. Research perspectives. Needham, MA: Sloan Consortium.

Prieto, A. S. (2016). Educational model of b-learning at Universidad Tecnológica de Chile-INACAP concepción-talcahuano. Academic results of 4 years of experience. REXE-Revista de Estudios y Experiencias en Educación, 9(18), 137-155.

Ramírez-Martinell, A., \& Maldonado Berea, G. A. (2015). Multimodalidad en educación superior [Multimodality in higher education]. In A. Ramírez \& M. Casillas (Eds.), Internet en educación superior (pp. 19-37). Córdoba, Spain: Brujas.

Robles Haros, B. I., Fernández Nistal, M. T., \& Vales García, J. J. (2016). Creencias de profesores universitarios sobre la enseñanza-aprendizaje de cursos b-learning revisión bibliográfica [Beliefs of university lecturers about teaching-learning in b-learning courses. Literature review]. EDMETIC, Revista de Educación Mediática y TIC, 5(2), 94-116.

Sadeck, O., \& Cronjé, J. (2017). A continuum of teachers' e-learning practices. Electronic Journal of e-Learning, 15(5), 396-409.

Sohrabi, B., Vanani, I. R., \& Iraj, H. (2019). The evolution of e-learning practices at the University of Tehran: A case study. Knowledge Management \& E-Learning, 11(1), 20-37.

Wang, X., Love, P., Klinc, R., Kim, M. J., \& Davis, P. R. (2012). Integration of elearning 2.0 with web 2.0. Journal of Information Technology in Construction, 17, 387-396.

Yang, H. H. (2013). New world, new learning: Trends and issues of e-learning. Procedia - Social and Behavioral Science, 77, 429-442.

Yilmaz, R. (2017). Exploring the role of e-learning readiness on student satisfaction and motivation in flipped classroom. Computers in Human Behavior, 70, 251-260.

Yilmaz, R., \& Keser, H. (2016). The impact of interactive environment and metacognitive support on academic achievement and transactional distance in online learning. Journal of Educational Computing Research, 55(1), 95-122. 


\section{Appendix I}

\section{Blended Learning Evaluation Scale (BLES)}

1. Are you male or female?
$\square$ Male
$\square$ Female

2. How old are you?

3. What is your city of residence?

4. What university degree are you studying?

$\square$ University Degree in Early Childhood Education

$\square$ University Degree in Primary Education

5. What previous studies do you have?
$\square$ Higher vocational training
Selectivity

$\square$ Another university degree, Which one?

$\square$ Other studies, Which?

6. What form of schooling are you enrolled in?

$\square$ face-to-face

$\square$ blended learning

7. Are you currently working?
$\square$ Yes
$\square$ No

8. How many hours do you work per week?
$\square$ Less than 10 hours
$\square$ Between 10 and 20 hours
$\square$ Between 20 and 30 hours
$\square$ More than 30 hours

9. Do you have a computer at home?
$\square$ Yes
$\square$ No

10. Do you have internet at home?
$\square$ Yes

$\square$ No

Answer the following questions with Yes or No:

\begin{tabular}{|rl|c|c|}
\hline \multicolumn{1}{|c|}{ QUESTION } & YES & NO \\
\hline $1 . \quad$ The virtual platform offers multiple functions & & \\
\hline $2 . \quad$ It is easy to manage on the virtual platform & & \\
\hline $3 . \quad$ You received initial training to learn how to use the virtual platform & & \\
\hline $4 . \quad$ The virtual platform includes technical assistance for difficulties & & \\
\hline
\end{tabular}




\begin{tabular}{|l|l|l|}
\hline 5. You use the virtual platform to inform you of exam dates & & \\
\hline $6 . \quad$ You use the virtual platform to check class days and schedule & & \\
\hline 7. You use the virtual platform to check marks & & \\
\hline 8. You use the virtual platform to consult library books & & \\
\hline 9. You use the virtual platform to communicate with your classmates & & \\
\hline 10. You use the virtual platform to communicate with professors & & \\
\hline 11. You use the virtual platform to deliver works & & \\
\hline 12. Documents posted by professor are easily understood & & \\
\hline 13. The professor proposes interactive talks on the virtual platform & & \\
\hline 14. The professor proposes forums on the virtual platform & & \\
\hline 15. The professor proposes blogs on the virtual platform & & \\
\hline 16. The professor includes the course notes on the virtual platform & & \\
\hline 17. The professor includes schemes on the virtual platform & & \\
\hline 18. The professor includes links to interesting websites on the virtual platform & & \\
\hline 19. The professor includes videos on the virtual platform & & \\
\hline 20. The professor includes self-assessments with automatic correction on the virtual platform & & \\
\hline 21. The professor includes self-assessments without automatic correction on the virtual platform & & \\
\hline 22. The professor includes model exams on the virtual platform & & \\
\hline 23. The professor includes glossaries on the virtual platform & & \\
\hline
\end{tabular}

Rate the following questions on a scale from 1 to 6 :
1- Not at all
3- Somewhat
5- A lot
2- A Little
4- Fairly
6- Very much

\begin{tabular}{|c|c|c|c|c|c|c|}
\hline QUESTION & 1 & 2 & 3 & 4 & 5 & 6 \\
\hline 1. Usefulness of asking questions by e-mail to professor & & & & & & \\
\hline 2. Usefulness of performing group work & & & & & & \\
\hline 3. Usefulness of presenting group work in class & & & & & & \\
\hline 4. Usefulness of the return of the work corrected by professor & & & & & & \\
\hline 5. Usefulness of delivering work to professor through the virtual platform & & & & & & \\
\hline 6. Usefulness of using chats through the virtual platform & & & & & & \\
\hline 7. Usefulness of using forums through the virtual platform & & & & & & \\
\hline 8. Usefulness of using blogs through the virtual platform & & & & & & \\
\hline 9. Closeness with professor & & & & & & \\
\hline 10. Closeness with classmates & & & & & & \\
\hline 11. Communication with professor & & & & & & \\
\hline 12. Usefulness of the subject for teaching practice & & & & & & \\
\hline 13. Applicability of contents in the classroom & & & & & & \\
\hline 14. Initial motivation towards the subject & & & & & & \\
\hline 15. Final motivation towards the subject & & & & & & \\
\hline
\end{tabular}

